\title{
Pengaruh Pemberian Serbuk Ekstrak Kelopak Bunga Rosela (Hibiscus sabdariffa $L$.) terhadap Sistem Imun Tikus Sprague Dawley
}

\section{The Effect of The Powder Extract Of Rosela Flower Petals (Hibiscus sabdariffa L.) on The Sprague Dawley Rats Immune System}

\author{
Mardiah $^{1 a}$, Dwi Ariyanti Nur'utami' ${ }^{1}$, dan Arti Hastuti ${ }^{1}$
}

${ }^{1}$ Jurusan Teknologi Pangan dan Gizi, Fakultas Ilmu Pangan Halal Universitas Djuanda Bogor

Jl. Tol Ciawi No.1, Kotak Pos 35 Ciawi, Bogor 16720

aKorespondensi: Mardiah, E-mail: mardiahrohmah@yahoo.com

(Diterima oleh Dewan Redaksi: 24 - 01 - 2019)

(Dipublikasikan oleh Dewan Redaksi: 30 - 04 - 2019)

\begin{abstract}
This study aims to determine the effect of the administration of extract powder roselle flower petals on the immune system of Sprague Dawley rats. The parameters observed were leukocyte count, differential leukocytes, lymphoid organs (spleen and liver), total serum protein and serum albumin from the blood of Sprague Dawley rats. Test animals were divided into four groups, each of which consisted of 5 rats. The first group was the normal group, group 2 was given stimuno forte dose of 1.35 $\mathrm{mg} / \mathrm{KgBB}$, group 3 was given extract powder I rosella dose of $40.5 \mathrm{mg} / \mathrm{KgBB}$, and group 4 was given extract powder II rosella dose of $81 \mathrm{mg} / \mathrm{KgBB}$ in a sonde for 28 days. On day 0 and day 29, blood is taken. Data analysis uses difference calculations, the results of which are compared with the normal values of healthy rats. Based on the results of research on the administration of extract powder I rosella dose $40.5 \mathrm{mg} / \mathrm{KgBB}$ can maintain immune system function in Sprague Dawley rats with an increase in the average value of segment neutrophils by $42.2 \%$, total serum protein of $10.99 \mathrm{~g} / \mathrm{dl}$, weight relative spleen of $0.22 \%$ and relative liver weight of $3.27 \%$ which is still within the normal range of experimental animals in healthy conditions which is still within the normal range of experimental animals in healthy condition so that it can provide a protective effect on antigen attack.
\end{abstract}

Keywords: Extract, rosela, immune System

\begin{abstract}
ABSTRAK
Penelitian ini bertujuan untuk mengetahui pengaruh pemberian serbuk ekstrak kelopak bunga rosela terhadap sistem imun tikus Sprague Dawley. Parameter yang diamati adalah leukosit, differensial leukosit, organ limfoid (limpa dan hati), total serum protein dan serum albumin dari darah tikus Sprague Dawley. Hewan uji dibagi atas 4 kelompok yang masing-masing terdiri dari 5 ekor tikus. Kelompok pertama adalah kelompok normal, kelompok 2 diberikan stimuno forte dosis 1,35 $\mathrm{mg} / \mathrm{KgBB}$, kelompok 3 diberikan serbuk ekstrak rosela I dosis 40,5 mg/KgBB, dan kelompok 4 diberikan serbuk ekstrak rosela II dosis $81 \mathrm{mg} / \mathrm{KgBB}$ secara sonde selama 28 hari. Pada hari ke-0 dan hari ke-29 dilakukan pengambilan darah. Analisa data menggunakan perhitungan selisih, yang hasilnya dibandingkan dengan nilai normal tikus kondisi sehat. Berdasarkan hasil penelitian pemberin serbuk ekstrak rosela I dosis 40,5 mg/KgBB KgBB dapat mempertahankan fungsi sistem imun pada tikus Sprague Dawley dengan peningkatan nilai rata-rata jumlah neutrofil segmen sebesar $42,2 \%$, total serum protein sebesar $10,99 \mathrm{~g} / \mathrm{dl}$, bobot limpa relatif sebesar $0,22 \%$ dan bobot hati relatif sebesar $3,27 \%$ yang masih dalam batas normal hewan coba dalam kondisi sehat sehingga dapat memberikan efek protektif terhadap serangan antigen.
\end{abstract}

Kata kunci: Serbuk ekstrak, rosela, sistem imun

Mardiah, Dwi Ariyanti Nur'utami, Arti Hastuti. 2019. Pengaruh Pemberian Serbuk Ektrak Kelopak Bunga Rosela (Hibiscus sabdariffa L.) terhadap Sistem Imun Tikus Sprague Dawley. Jurnal Agroindustri Halal 5(1): 017 - 029. 


\section{PENDAHULUAN}

Sistem imun merupakan suatu sistem pertahanan tubuh agar kondisi tubuh tetap sehat, upaya untuk meningkatkan sistem imun sangat penting. Proses penuaan dan penyakit degeneratif seperti kanker, tekanan darah tinggi, stroke, serta terganggunya sistem imun tubuh adalah beberapa penyakit yang berkaitan dengan radikal bebas. Banyak sekali sumber radikal bebas yang dapat masuk dan terbentuk dalam tubuh, diantaranya melalui pernafasan, lingkungan yang tidak sehat, dan banyak mengkonsumsi makanan yang berlemak ataupun yang tidak sehat. Menurut Ulilalbab et al. (2010) radikal bebas dapat dihambat dengan antioksidan

Sistem imun dapat ditingkatkan dengan mengkonsumsi makanan yang mengandung komponen zat aktif seperti antioksidan yang dapat diperoleh dari bahan alami seperti pada kelopak bunga Rosela. Komponen zat aktif yang terkandung dalam rosela yaitu antioksidan tinggi (flavonoid, fitosterol, vitamin $\mathrm{C}$ ) dan zat gizi yang baik (asam amino lengkap, kandungan vitamin $\mathrm{B}$, dan mineralnya tinggi). Menurut penelitian Mardiah et al. (2015) kelompok tikus yang diberi dosis $72 \mathrm{mg}$ rosela/hari/200gBB dan $288 \mathrm{mg} /$ hari/200 gBB cenderung memiliki kadar TNF- $\alpha$ yang rendah. Hal ini menunjukkan bahwa rosela mampu mengurangi peradangan (inflamasi) atau antiinflamasi. Rosela juga mampu menurunkan viskositas darah, membantu proses penyerapan zat gizi serta mempunyai dampak untuk meyembuhkan penyakit TBC serta zat aktifnya mampu berfungsi sebagai bahan detoksifikasi. Penelitian fungsional yang telah diuji adalah kemampuan ekstrak rosela sebagai antidiabetes melalui mekanisme peningkatan sel beta penghasil insulin dan sebagai antiinflamasi (Mardiah et al., 2014; Mardiah et al., 2015). Selama ini rosela sudah diolah menjadi beberapa produk pangan seperti permen jelly (Rahadian et al., 2017), teh (Dwiyanti et al., 2014), Sirup (Yati et al., 2014), dan minuman fungsional (Mardiah et al., 2014).

Melihat pemanfaatan rosela yang cukup luas terutama sebagai antioksidan sedangkan produk serbuk ekstrak dalam bidang farmakologi masih terbatas. Dalam kajian penelitian ini serbuk ekstrak rosela yang ingin dihasilkan adalah serbuk ekstrak rosela yang mampu menyediakan zat aktif (fitokimia) yang terkandung di dalamnya dengan harapan berperan terhadap sistem imun. Sehingga dapat memberikan efek kesehatan bagi orang yang mengkonsumsinya. Tujuan umum dari penelitian ini adalah untuk mengembangkan diversifikasi pangan dalam hal pembuatan produk ekstrak rosela rosela yang merupakan produk suplemen minuman fungsional berbahan baku herbal alami dari kelopak bunga rosela. Tujuan khusus dari penelitian ini adalah untuk mengetahui pengaruh pemberian serbuk ekstrak kelopak bunga rosela (Hibiscus sabdariffa L.) terhadap sistem imun tikus Sprague Dawley pada parameter leukosit, differensial leukosit (neutrofil, limfosit, eosinofil, monosit), total serum protein, albumin, dan bobot organ limfoid (limpa dan hati).

\section{METODE PENELITIAN}

Bahan yang digunakan yaitu produk dari kelopak rosela yang dibuat menjadi serbuk ekstrak, stimuno forte adalah sejenis suplemen yang termasuk grup imunomodulator atau perangsang sistem kekebalan tubuh, hewan coba yang digunakan tikus putih (Rattus norvegicus) galur Sprague Dawley berumur 2 bulan dengan berat 300gram yang diperoleh dari Laboratorium Unit Kandang Hewan Percobaan Pusat Studi Biofarmaka LPPMIPB. Alat yang akan digunakan dalam penelitian ini adalah peralatan gelas, evaporator vakum, mortar, beeding /sekam, sonde lambung, syringe $1 \mathrm{cc}$, syring $3 \mathrm{cc}$, kandang jepit, boks kandang, rak tikus Serta alat-alat yang akan digunakan untuk analisa sistem imun.

\section{Tempat dan Waktu Penelitian}

Penelitian dilaksanakan di Laboratorium Sains dan Pengolahan Pangan 
Jurusan Teknologi Pangan dan Gizi, Fakultas Ilmu Pangan Halal, Universitas Djuanda Bogor, Laboratorium Lembaga Farmasi Angkatan Laut (LAFIAL) Jakarta, dan Laboratorium Unit Kandang Hewan Percoban Pusat Studi Biofarmaka LPPM-IPB. Penelitian dilaksanakan dari bulan Mei sampai Juli 2018.

\section{Metode Penelitian}

Penelitian ini terdiri dari dua tahap yaitu tahap ekstraksi dan perlakuan hewan coba.

\section{Tahap Ekstraksi}

Tahap ini merupakan tahap proses ekstraksi antosianin dari kelopak bunga rosela dengan menggunakan 2 jenis enzim yaitu enzim pektinase dan enzim selulase. (Modifikasi Mardiah et al., 2014) yang dapat dilihat pada gambar 1 .

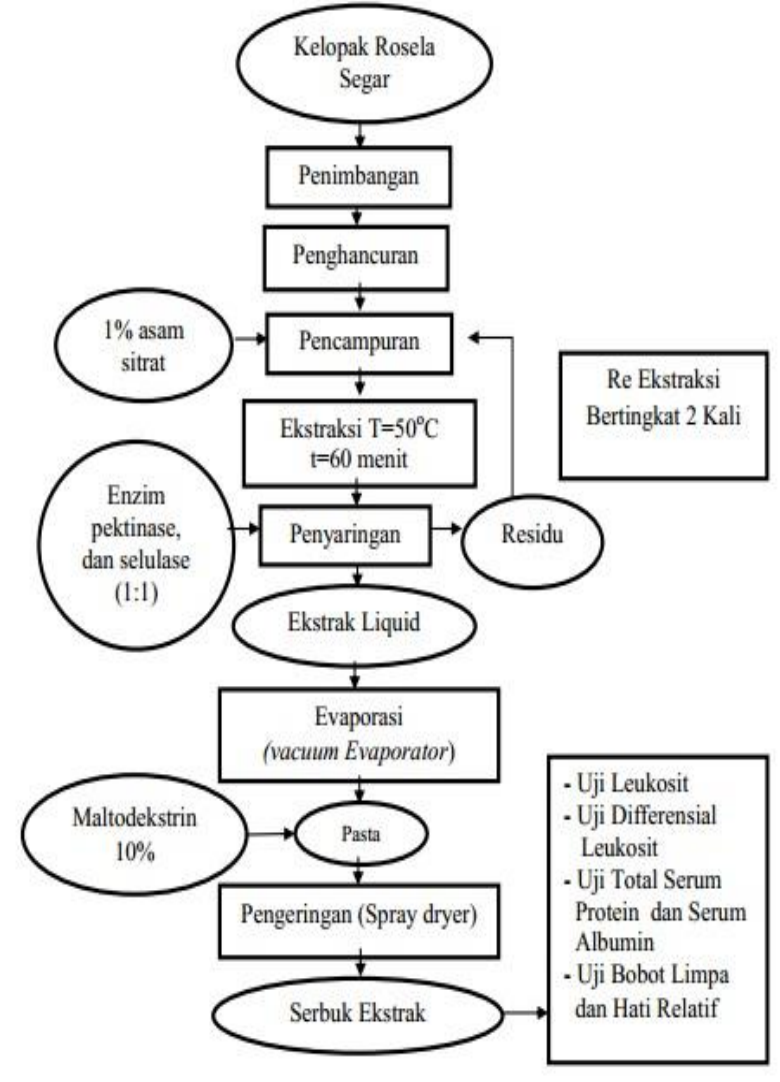

Gambar 1. Diagram Alir Pembuatan Serbuk Ekstrak Rosela (Modifikasi Mardiah et al., 2014).

\section{Perlakuan Hewan Percobaan}

Penimbangan dua puluh ekor tikus putih (Rattus novergicus) strain Sprague
Dawley berumur 2 bulan dengan bobot badan 300g dikandangkan pada suhu ruang dan diberikan pakan standar dan menerima air secara ad libitum. Tikus dibagi kedalam tiga kelompok perlakuan yang masing-masing terdiri atas 5 ekor.

Perlakuan terdiri:

A1 = Kontrol

A2 $=$ Pemberian stimuno forte dosis 1,35 $\mathrm{mg} / \mathrm{kgBB}$

$\mathrm{A} 3=$ Pemberian serbuk ekstrak dosis

$$
\text { 40,5 mg/KgBB }
$$

$\mathrm{A} 4=$ Pemberian serbuk ekstrak dosis

$$
81 \mathrm{mg} / \mathrm{KgBB}
$$

Dilakukan pengadaptasian hewan coba selama 7 hari, kemudian pengambilan darah hari ke-0. Selanjutnya, masing-masing perlakuan diberikan sampel secara sonde 1 kali sehari selama 28 hari. Pada hari ke-29 hewan coba diambil darah untuk diuji: jumlah leukosit, jenis leukosit (differensial leukosit), total serum protein serta serum albumin, kemudian hewan dikorbankan ditimbang organ limfoid (limpa \& hati).

\section{Analisa Metode}

Dalam penelitian ini meliputi Uji Jumlah leukosit (Hematologi) (Sullivan, 2006) terhadap semua sampel darah tikus, uji jenis leukosit (Differensial leukosit) (Sastradipradja et al., 1989) dengan menggunakan alat Differential Count Manual. Uji perhitungan total protein serum dan albumin Serum (Fatchiyat et al., 2011) menggunakan mesin Biochemistry Analyzer Photometer I-Chem 535, dan perhitungan bobot organ limfoid relatif (Aldi et al., 2016). Selanjutnya dianalisis data digunakan dalam penelitian ini adalah model matematis untuk mengetahui perubahan pada pengamatan digunakan dengan matematika sederhana perhitungan selisih, yang hasilnya dibandingkan dengan nilai normal tikus kondisi sehat. 


\section{HASIL DAN PEMBAHASAN}

\section{Hasil Uji Jumlah Leukosit}

Leukosit merupakan salah satu sistem pertahanan tubuh atau komponen aktif yang dibentuk sebagian di dalam sumsum tulang dan sebagian di dalam organ limfoid seperti hati dan limpa. Sel leukosit mampu keluar dari pembuluh darah dan menuju ke jaringan-jaringan yang membutuhkan (Ganong, 1996).

Rata-rata jumlah leukosit darah tikus pada perlakuan A1, A2, A3 dan A4 setelah diberi perlakuan selama 28 hari berturutturut dapat dilihat pada Tabel 1.

Tabel 1. Nilai Rata•Rata Jumlah Leukosit ( $\left.\times 10^{3} / / \mathrm{LL}\right)$

\begin{tabular}{|c|c|c|c|c|c|}
\hline Waktu & $\mathrm{Al}$ & $\mathrm{A}^{2} 2$ & $\mathrm{~A}^{3}$ & A4 & Normal \\
\hline Hari Ke.0 & 10,78 & 10,56 & 10,06 & 12,50 & \multirow{2}{*}{$5-25$} \\
\hline Hari Ke.29) & 8,84 & 8,44 & 5,24 & 12,14 & \\
\hline Selisih & $.1,94$ & 2,12 & 4,82 & $.0,36$ & \\
\hline
\end{tabular}

Berdasarkan pada Tabel 1 pada hari ke0 sampai hari ke-29 menunjukan adanya penurunan jumlah leukosit yang ditandai dengan nilai selisih negatif, tetapi apabila dilihat perlakuan A4 (Pemberian Serbuk Ekstrak II dosis $81 \mathrm{mg} / \mathrm{KgBB}$ ) mampu mempertahankan jumlah leukosit dibandingkan dengan perlakuan A1 (kontrol normal), A2 (Pemberian Stimuno Forte dosis 1,35 mg/KgBB) dan A3 (Pemberian Serbuk Ekstrak I dosis 40,5 mg/KgBB). Perlakuan A4 (Pemberian Serbuk Ekstrak II dosis 81 $\mathrm{mg} / \mathrm{KgBB}$ ) memiliki nilai selisih yang lebih kecil, yaitu sebesar $-0,36$ (jumlah nilai rataan leukosit sebesar $\left.12,14 \times 10^{3} / \mu \mathrm{L}\right)$ dibandingkan perlakuan A1 (kontrol normal) dengan nilai selisih $-1,94$ (jumlah nilai rataan leukosit sebesar $\left.8,84 \times 10^{3} / \mu \mathrm{L}\right), \quad$ A2 (Pemberian Stimuno Forte dosis 1,35 $\mathrm{mg} / \mathrm{KgBB}$ ) nilai selisih sebesar -2,12 (jumlah nilai rataan leukosit sebesar $8,44 \times 10^{3} / \mu \mathrm{L}$ ) dan perlakuan A3 (Pemberian Serbuk Ekstrak I dosis 40,5 mg/KgBB) nilai selisih sebesar $-4,82$ (jumlah nilai rataan leukosit sebesar $\left.5,24 \times 10^{3} / \mu \mathrm{L}\right)$. Hal ini dapat disebabkan dosis yang lebih tinggi pada perlakuan A4 (Pemberian Serbuk Ekstrak II dosis $81 \mathrm{mg} / \mathrm{KgBB}$ ) dibandingkan A3 (Pemberian Serbuk Ekstrak I dosis 40,5 $\mathrm{mg} / \mathrm{KgBB}$ ) sehingga memungkinkan lebih tingginya kandungan antosianin yang bersifat antioksidan dalam serbuk ekstrak rosela tersebut yang berperan menangkal radikal bebas dengan mempertahankan fungsi sistem imun tikus Sprague Dawley terhadap serangan antigen sehingga mampu mempertahankan jumlah leukosit dalam kisaran normal.

Mekanisme senyawa antioksidan mempertahankan jumlah leukosit dibatas normal mengindikasikan senyawa tersebut memberikan efek protektif terhadap serangan antigen tikus Sprague Dawley. Menurut penelitian Setiawan (2013) menyatakan flavonoid yang bersifat antioksidan pada madu murni memiliki kemampuan antiimflamasi melalui penghambatan pelepasan faktor-faktor proimflamasi, dengan jalan memodulasi sistem imun dan berperan sebagai antioksidan yang berfungsi menetralkan radikal bebas yang terjadi pada proses inflamasi.

Flavonoid yang bersifat antioksidan merupakan inhibitor yang digunakan untuk menghambat autooksidasi keterganggunya sistem imun akibat radikal bebas, menurut Nurarita et al., (2012) menyatakan antioksidan mampu meningkatan jumlah leukosit sebagai sistem pertahanan pada pasien yang mengalami penyakit periodontal yang disebabkan adanya reaktive oxygen spesies yang distimulasi oleh antigen. Mekanismenya antioksidan mempunyai kemampuan untuk menetralkan radikal bebas dalam memberikan (donasi) elektron untuk melindungi dari efek merusak radikal yang sangat reaktif atau dengan cara mengubah Reactive Oxygen Species (ROS) menjadi molekul tidak berbahaya untuk tubuh (Silalahi, 2006).

Penurunan jumlah leukosit yang terjadi pada setiap perlakuan dapat disebabkan oleh pengaruh biokimia tubuh yang sama, ketika dimasukan kedalam tubuh hewan reaksinya 
sama, penurunan jumlah leukosit dapat disebabkan pula oleh migrasi leukosit dari darah perifer ke jaringan yang membutuhkan (Widyastuti, 2013). Selain itu, kondisi tubuh, usia hewan coba dapat mempengaruhi produksi leukosit dan tidak adanya antigen yang menginfeksi tubuh hewan coba terkait pemberian sampel dan hewan coba dalam keadaan sehat selama proses penelitian (29 hari). Tetapi, pada setiap perlakuan masih dalam batas jumlah leukosit normal tikus yaitu $5 \times 10^{3} / \mu \mathrm{L}-25 \times 10^{3} / \mu \mathrm{L}$ (Aboderin dan Oyetayo, 2006).

\section{Hasil Uji Jenis Leukosit (Differensial Leukosit)}

\section{Neutrofil}

Neutrofil adalah jenis sel leukosit yang berperan dalam pertahanan tubuh terhadap benda asing. Neutrofil terbagi menjadi dua yaitu neutrofil segmen (polimorfonuklear) dan neutrofil batang (stab). Perbedaannya yaitu neutrofil batang merupakan bentuk neutrofil muda dari neutrofil segmen yang mempunyai inti seperti tapal kuda. Seiring dengan proses pematangan, bentuk intinya akan bersegmen dan akan menjadi neutrofil segmen (Riswanto, 2013). Neutrofil segmen disebut neutrofil polimorfonuklir karena sel intinya terdiri dari 2-5 segmen (lobus) (Kiswari 2014). Hasil penelitian nilai ratarata jumlah neutrofil dapat dilihat pada Tabel 2.

Tabel 2. Nilai Rata-Rata Jumlah Neutrofil (\%)

\begin{tabular}{|c|c|c|c|c|c|c|}
\hline Parameter & Waktu & $\mathrm{Al}$ & $\mathrm{A} 2$ & $\mathrm{A3}^{3}$ & A4 & Normal \\
\hline \multirow{3}{*}{$\begin{array}{l}\text { Neutrofil } \\
\text { Segmen }\end{array}$} & Hari Ke-0 & 28,0 & 38,6 & 28,2 & 28,4 & \multirow{2}{*}{$40-70$} \\
\hline & Hari Ke-29 & 34,8 & 28,4 & 42,2 & 24,4 & \\
\hline & Selisih & 6,8 & $-10,2$ & 14 & 4 & \\
\hline \multirow{3}{*}{$\begin{array}{c}\text { Neutrofil } \\
\text { Batang } \\
\end{array}$} & Hari Ke-0 & 0,2 & 1,4 & 0,8 & 0,4 & \multirow{2}{*}{$2 \cdot 6$} \\
\hline & Hari Ke-29 & 0,8 & 0,6 & 0,0 & 0,2 & \\
\hline & Selisih & 0,6 & $-0,8$ & $-0,8$ & $-0,2$ & \\
\hline
\end{tabular}

Berdasarkan Tabel 2 pada parameter neutrofil segmen hari ke-0 sampai hari ke-29 menunjukan peningkatan terbesar pada perlakuan A3 (Pemberian Serbuk Ekstrak I dosis 40,5 mg/KgBB) dengan nilai selisih sebesar 14 (jumlah nilai rataan neutrofil segmen sebesar 42,2\%) dibandingkan perlakuan A1 (kontrol normal) nilai selisih sebesar 6,8 (jumlah nilai rataan neutrofil segmen sebesar 34,8\%), A2 (Pemberian Stimuno Forte dosis $1,35 \mathrm{mg} / \mathrm{KgBB}$ ) nilai selisih sebesar $-10,2$ (jumlah nilai rataan neutrofil segmen sebesar 34,8\%), dan A4 (Pemberian Serbuk Ekstrak II dosis 81 $\mathrm{mg} / \mathrm{KgBB}$ ) nilai selisih sebesar -4 (jumlah nilai rataan neutrofil segmen sebesar $24,4 \%$ ). Hal ini menunjukan pada perlakuan A3 (Pemberian Serbuk Ekstrak I dosis 40,5 $\mathrm{mg} / \mathrm{KgBB}$ ) efektif dalam meningkatkan neutrofil segmen yang dapat dilihat pada nilai terbesar selisih positif dan masih dalam kisaran batas normal hewan coba $40-70 \%$ (Santoso, 2010). Ekstrak rosela memiliki kandungan antosianin yang bersifat antioksidan, pada tikus Sprague Dawley yang diberikan ekstrak rosela mengandung senyawa antosianin yang bersifat antioksida memberikan efek protektif terhadap serangan antigen dengan meningkatkan jumlah nilai rataan neutrofil segmen dibandingkan perlakuan lainnya.

Menurut penelitian Mardiah et al. (2014) menyatakan pemberian rosela pada tikus dapat meningkatkan kapasitas total antioksidan. Pigmen antosianin pada rosela dapat menurunkan stres oksidatif akibat radikal bebas. Mekanisme antioksidan pada kemampuan rosela yang dapat menyumbangkan ion $\mathrm{H}^{+}$yang berfungsi sebagai cleator logam (mengandung polifenol) yang dapat mengikat $\mathrm{Fe}^{2+}$ yang menurunkan reaksi fenton dan mencegah oksidasi yang disebabkan oleh peningkatan radikal hidroksil (ROS). Perawatan dengan ekstrak rosela mampu meningkatkan kapasitas antioksidan yang mampu meningkatkan jumlah neutrofil berfungsi sebagai sistem pertahanan yang bersifat fagosit terhadap benda asing.

Berdasarkan Tabel 2 pada parameter neutrofil batang hari ke-0 sampai hari ke-29 pada setiap pemberian sampel mengalami penurunan perlakuan A2 (Pemberian Stimuno Forte dosis 1,35 mg/KgBB), A3 (Pemberian Serbuk Ekstrak I dosis 40,5 mg/KgBB), A4 (Pemberian Serbuk Ekstrak II 
dosis $81 \mathrm{mg} / \mathrm{KgBB})$ dibandingkan A1 (kontrol normal) yang mengalami peningkatan dengan selisih sebesar 0,6, akan tetapi apabila dilihat pada setiap perlakuan masih dibawah batas normal jumlah neutrofil batang yaitu sebesar 2-6 \% (Santoso, 2010).

Menurut Atmadja et al., (2016) menyatakan peningkatan jumlah neutrofil di atas batas normal dapat disebabkan oleh adanya stres fisik atau emosional ketidaknyamanan pada saat pengambilan darah atau pun kondisi lingkungannya yang kurang kondusif, selain itu dapat disebabkan trauma, dan kelainan metabolik. Sedangkan penurunan jumlah neutrofil dibawah batas normal dapat disebabkan oleh adanya defisinsi zat gizi, infeksi bakteri dan infeksi virus (misalnya infulenza, hepatitis, campak) ataupun penurunan jumlah neutrofil yang terjadi pada penelitian dimungkinkan karena waktu edar neutrofil dalam sirkulasi darah yang hanya 6-7 jam, sehingga memungkinkan jumlah nilai rata-rata neutrofil menurun dalam sirkulasi darah yang berdistribusi ke jaringan (Widyastuti, 2013).

Menurut Guyton (1983) menyatakan setiap antibodi bersifat spesifik untuk antigen tertentu. Mekanisme hubungan jumlah neutrofil sebagai efek protektif terhadap serangan antigen yaitu neutrofil berfungsi untuk menjaga keseimbangan sistem imun terhadap pengaruh benda asing. Neutrofil sangat aktif dan fagosit, setelah berada di jaringan terinfeksi sel-sel yang menghancurkan, menyerang bakteri dan virus.

\section{Limfosit}

Limfosit merupakan jenis leukosit yang plasmanya tidak bergranula (agranulosit) yang berperan dalam reaksi sistem imun terhadap serangan benda asing, mikroorganisme, maupun sel-sel kanker (Junqueirq dan Carneiro, 2004). Hasil penelitian nilai rata-rata jumlah limfosit dapat dilihat pada Tabel 3.
Tabel 3. Nilai Rata-Rata Jumlah Limfosit (\%)

\begin{tabular}{|c|c|c|c|c|c|}
\hline Waktu & $\mathrm{Al}$ & A2 & $\mathrm{A}^{3}$ & A4 & Normal \\
\hline Hari ke-0 & 69,6 & 58,0 & 69,2 & 70,4 & \multirow{2}{*}{55.85} \\
\hline Hari ke-29 & 62 & 65,2 & 55,6 & 73,0 & \\
\hline Selisih & $.7,6$ & 7,2 & $.13,6$ & 2,6 & \\
\hline $\begin{aligned} \text { gan }: \text { Al } \\
\text { Pem } \\
\text { Ekst }\end{aligned}$ & Norm & $\begin{array}{l}\text { Pemb } \\
\text { I dosi }\end{array}$ & & & $\begin{array}{l}\text { KgBB, } \\
\text { crbuk }\end{array}$ \\
\hline
\end{tabular}

Berdasarkan Tabel 3 jumlah nilai rataan limfosit pada hari ke-0 sampai hari ke-29 megalami peningkatan pada perlakuan A2 (Pemberian Stimuno Forte dosis 1,35 $\mathrm{mg} / \mathrm{KgBB})$ dengan nilai selisih positif sebesar 7,2 (jumlah nilai rataan limfosit sebesar 65,2\%) dan A4 (Pemberian Serbuk Ekstrak II dosis $81 \mathrm{mg} / \mathrm{KgBB}$ ) nilai selisih sebesar 2,6 (jumlah nilai rataan limfosit sebesar 73\%) dibandingkan perlakuan A1 (kontrol normal) nilai selisih -7,6 (jumlah nilai rataan limfosit sebesar 62\%) dan A3 (Pemberian Serbuk Ekstrak I dosis 40,5 $\mathrm{mg} / \mathrm{KgBB}$ ) nilai selisih sebesar $-13,6$ (jumlah nilai rataan limfosit sebesar 55,6\%) yang mengalami penurunan jumlah limfosit. Hal ini dapat disebabkan peran kandungan senyawa aktif pada stimuno forte. Stimuno forte merupakan produk dari tanaman ekstrak meniran (phyllanthus niruri) yaitu sejenis suplemen yang termasuk dalam grup imunomodulator alami atau perangsang sistem kekebalan hal ini dibuktikan telah dipatenkannya meniran sebagai obat stimuno (Sulaksana dan Jayusman, 2004).

Menurut Wibowo (2009) menyatakan senyawa yang terkandung di dalam meniran yaitu flavonoid dan ligan (filantin, hipofilantin, lintetratin, nirantin) yang merupakan golongan antioksidan. Sedangkan pada perlakuan A4 (Pemberian Serbuk Ekstrak II dosis $81 \mathrm{mg} / \mathrm{KgBB}$ ) senyawa aktif yang terkandung dalam ekstrak rosela yaitu senyawa antosianin termasuk golongan flavonoid yang bersifat antioksidan yang berperan menangkal radikal bebas mekanisme kerjanya dengan mendonorkan atom $\mathrm{H}^{+}$dari fenolik hidrogen sehingga radikal bebas menjadi stabil. Senyawa antioksidan ini dapat berperan pada sistem imunitas tubuh sehingga dapat 
meningkatkan jumlah limfosit yang masih dalam batas kisaran normal tikus (kondisi sehat) 55-85\% (Smith dan Mangkoewidjojo, 1988).

Parameter limfosit berhubungan proteksi terhadap sistem imun karena mekanisme kerja limfosit berhubungan dengan respon sistem imun, kemampuan limfosit dengan senyawa zat aktif yang dapat memodulasi sistem imun dalam aktivitas produksi antibodi pembentukan pertahanan spesifik. Apabila jaringan rusak dan adanya invasi mikroorganisme didalam tubuh akan merangsang aktivitas sel makrofag sehingga merangsang kerja limfosit $\mathrm{T}$ dan limfosit B. Di dalam tubuh limfosit $\mathrm{T}$ bermigrasi kedalam jaringan dan langsung menyerang benda asing pada jaringan tersebut, sedangkan sel B akan berdiferensiasi menjadi sel plasma yang mensekresi antibodi dan akan menyerang patogen (Jain, 1993)

Peningkatan sel limfosit diatas batas normal dapat disebabkan oleh setres, baik emosional maupun kronis, sedangkan penurunan jumlah limfosit dibawah batas normal dapat disebabkan karena adanya infeksi virus. Pada penelitian ini tikus yang digunakan tidak dilakukan infeksi dan masih dalam keadaan sehat (29 hari) sehingga penurunan jumlah limfosit dapat disebabkan oleh distribusi limfosit ke jaringan (Widyastuti, 2013).

\section{Eosinofil}

Eosinofil merupakan leukosit yang sitoplasmanya bergranula berwarna eosin yaitu merah. Eosinofil berperan dalam serangan parasit, reaksi alergi dan jumlah akan meningkat selama serangan alergi. Eosinofil bersifat fagositik terutama terhadap antigen (Malvin dan William 1993). Hasil penelitian nilai rata-rata jumlah eosinofil dapat dilihat pada Tabel 4.
Tabel 4. Nilai Rata-Rata Jumlah Eosinofil (\%)

\begin{tabular}{|c|c|c|c|c|c|}
\hline Waktu & $\mathrm{Al}$ & A2 & A3 & $\overline{\mathrm{A} 4}$ & Normal \\
\hline Hari ke-0 & 1,0 & 1,0 & 1,2 & 0,6 & \multirow{2}{*}{$0,2-4,0$} \\
\hline Hari ke-29 & 1,6 & 3,4 & 1,6 & 1,4 & \\
\hline Selisih & 0,6 & 2,4 & 0,4 & 0,8 & \\
\hline
\end{tabular}

Berdasarkan Tabel 4 pada hari ke-0 sampai hari ke-29 pemberian sampel menunjukan adanya peningkatan jumlah eosinofil yang ditandai nilai selisih positif pada setiap perlakuan. Peningkatan nilai terbesar pada perlakuan A2 (Pemberian Stimuno Forte dosis 1,35 mg/KgBB) dengan nilai selisih sebesar 2,4 (jumlah nilai rataan eosinofil sebesar 3,4\%) dibandingkan perlakuan A1 (kontrol normal) nilai selisih sebesar 0,6 (jumlah nilai rataan eosinofil sebesar 1,6\%), A3 (Pemberian Serbuk Ekstrak I dosis 40,5 mg/KgBB) nilai selisih sebesar 0,4 (jumlah nilai rataan eosinofil sebesar 1,6\%), dan A4 (Pemberian Serbuk Ekstrak II dosis $81 \mathrm{mg} / \mathrm{KgBB}$ ) nilai selisih sebesar 0,8 (jumlah nilai rataan eosinofil sebesar 1,4). Hal tersebut menunjukan perlakuan A2 (Pemberian Stimuno Forte dosis $1,35 \mathrm{mg} / \mathrm{KgBB}$ ) mengandung senyawa antioksidan yang efektif dalam meningkatkan jumlah eosinofil yang masih dalam batas nilai normal jumlah eosinofil hewan coba tikus normal (kondisi sehat).

Peningkatan jumlah eosinofil tidak dapat diindikasikan adanya respon imun terhadap infeksi atau alergi karena jumlah yang diperoleh dalam setiap perlakuan masih tergolong jumlah eosinofil normal tikus, yaitu 0,2-4,0\% (Primawati dan Khalid, 2015).

Menurut Guyton (1983) menyatakan setiap antibodi bersifat spesifik untuk antigen tertentu. Eosinofil berperan dalam detoksifikasi histamin pada reaksi alergi. Mekanisme kerja eosinofil mengandung enzim fosfatase dan feroksidase enzim ini yang berperan dalam detoksifikasi bakteri dengan memindahkan komplek antigenantibodi. 
Hasil penelitian nilai rata-rata jumlah monosit dapat dilihat pada Tabel 5.

Tabel 5. Nilai Rata-Rata Jumlah Monosit (\%)

\begin{tabular}{|c|c|c|c|c|c|}
\hline Waktu & $\mathrm{Al}$ & $\mathrm{A} 2$ & $\mathrm{A3}$ & $\mathrm{A} 4$ & Normal \\
\hline Hari ke-0) & 1,4 & 1,0 & 0,6 & 0,2 & \multirow{2}{*}{3.8} \\
\hline Hari ke-29 & 0,8 & 2,4 & 0,6 & 1,0 & \\
\hline Selisih & $-0,6$ & 1,4 & 0,0 & 0,8 & \\
\hline
\end{tabular}

Berdasarkan Tabel 5 pada hari ke-0 sampai hari ke-29 pemberian sampel menunjukan adanya peningkatan pada perlakuan A2 (Pemberian Stimuno Forte dosis 1,35 mg/KgBB) dengan nilai selisih sebesar 1,4 (jumlah nilai rataan monosit sebesar 2,4\%) dan A4 (Pemberian Serbuk Ekstrak II dosis $81 \mathrm{mg} / \mathrm{KgBB}$ ) nilai selisih sebesar 0,8 (jumlah nilai rataan monosit sebesar 1\%). Peningkatan yang terjadi dapat disebabkan kandungan senyawa yang terdapat pada stimuno forte dan serbuk ekstrak rosela yang mempunyai efek proteksi terhadap sistem imun karena dapat meningkatkan jumlah monosit dibandingkan perlakuan yang lain. Sedangkan penurunan yang terjadi pada perlakuan A1 (kontrol normal) dengan nilai selisih sebesar $-0,6$ (jumlah nilai rataan monosit sebesar 0,8\%) hal ini dapat disebabkan karena pada kelompok tersebut tikus tidak diberikan sampel apapun dan perlakuan A3 (Pemberian Serbuk Ekstrak I dosis 40,5 $\mathrm{mg} / \mathrm{KgBB}$ ) menunjukan nilai rataan jumlah monosit yang stagnan hal tersebut menunjukan ada atau tidaknya pemberian sampel pada perlakuan A3 (Pemberian Serbuk Ekstrak I dosis 40,5 mg/KgBB) tidak berpengaruh pada jumlah nilai rataan monosit.

Hasil penelitian pada setiap perlakuan menunjukan dibawah kisaran normal monosit yaitu 3-8\% (Kiswari, 2014). Hal tesebut dapat disebabkan pada penelitian ini hewan coba tidak diinduksi jamur ataupun bakteri yang penyebabkan penyakit sehingga tidak berpengaruh terhadap produksi sel monosit secara optimal. Menurut Frandson (1992) menyatakan monosit berperan sebagai fagosit mikroorganisme (khususnya jamur dan bakteri) serta berperan dalam respon protektif terhadap serangan antigen. Adapun penurunan jumlah monosit dapat pula disebababkan kemampuan sel monosit yang dapat berpindah dari darah perifer ke jaringan yang membutuhkan (Widyastuti, 2013).

\section{Total Serum Protein dan Albumin Serum}

Hasil penelitian uji total serum protein dan serum albumin pada tikus Sprague Dawley dapat dilihat pada Tabel 6.

Tabel 6. Hasil Uji Total Serum Protein dan Serum Albumin (g/dl)

\begin{tabular}{|c|c|c|c|c|c|c|}
\hline Parameter & Waktu & $\mathrm{Al}$ & $\mathrm{A} 2$ & $\mathrm{A3}$ & $\mathrm{A4}$ & Normal \\
\hline \multirow{3}{*}{$\begin{array}{c}\text { Serum } \\
\text { Protein } \\
\text { (g/dl) }\end{array}$} & Hari ke-0 & 10,48 & 9,85 & 10,18 & 10,09 & \\
\hline & Hari ke-29 & 10,39 & 9,94 & 10,99 & 10,75 & \\
\hline & Selisih & $-0,09$ & 0,09 & 0,81 & 0,66 & \\
\hline \multirow{3}{*}{$\begin{array}{c}\text { Serum } \\
\text { Albumin } \\
(\mathrm{g} / \mathrm{dl})\end{array}$} & Hari ke-0 & 1,59 & 1,65 & 1,64 & 1,71 & \multirow[b]{2}{*}{$3,0-5,1$} \\
\hline & Hari ke-29 & 1,44 & 1,42 & 1,53 & 1,53 & \\
\hline & Selisih & $-0,15$ & $-0,23$ & $-0,11$ & $-0,18$ & \\
\hline
\end{tabular}

\section{Serum Protein}

Berdasarkan Tabel 6 pada hari ke-0 sampai hari ke-29 pemberian sampel menunjukkan peningkatan terbesar jumlah nilai rataan serum protein pada perlakuan A3 (Pemberian Serbuk Ekstrak I dosis 40,5 $\mathrm{mg} / \mathrm{KgBB}$ ) dengan nilai selisih 0,81 (jumlah nilai rataan serum protein $10,99 \mathrm{~g} / \mathrm{dl}$ ) dibandingkan perlakuan A1 (kontrol normal) dengan nilai selisih $-0,09$ (jumlah nilai rataan serum protein 10,39g/dl), A2 (Pemberian Stimuno Forte dosis 1,35 mg/KgBB) dengan nilai selisih 0,09 (jumlah nilai rataan serum protein 9,94g/dl) dan A4 (Pemberian Serbuk Ekstrak II dosis $81 \mathrm{mg} / \mathrm{KgBB}$ ) dengan nilai selisih 0,66 (jumlah nilai rataan serum protein $10,75 \mathrm{~g} / \mathrm{dl}$ ). Hal ini menunjukan perlakuan A3 (Pemberian Serbuk Ekstrak I dosis 40,5 mg/KgBB) lebih efektif dalam meningkatan jumlah kadar serum protein, peningkatan jumlah nilai rataan serum protein dapat disebabkan biokimia tubuh yang merespon metabolisme protein didalam tubuh hewan coba sehingga memberikan 
efek protetif terhadap sistem imun tikus Sprague Dawley.

Menurut Azza et al. (2007) menyatakan kelopak rosela mengandung protein sebesar $7,51 \%$, dengan pemberian ekstrak rosela yang juga mengandung protein, telah dapat dimetabolisme menjadi asam amino yang juga akan masuk kedalam serum dan mengindiksasikan meningkatkan metabolisme protein (Aprilia, 2012). Menurut Etim et al. (2014) Salah satu fungsi serum protein dalam biokimia darah berperan untuk pembentukan antibodi atau leukosit, protein juga dapat memperbaiki fungsi tubuh yang terganggu. Sehingga, pengujian total serum protein ini dapat berperan protektif terhadap serangan antigen.

Penurunan nilai rataan serum protein dapat dilihat pada Tabel 6 yaitu perlakuan A1 (kontrol normal) dengan nilai rataan jumlah serum protein sebesar $-0,09$. Hal tersebut dapat disebabkan karena pola asupan nutrisi yang kurang, kelompok hewan coba yang tidak dilakukan pemberian sampel yang mengandung senyawa aktif.

Mekanisme peran serum protein didalam tubuh yang berperan pada sistem imunitas yaitu plasma glikoprotein yang bersirkulasi dan dapat berinteraksi secara spesifik dengan determinan antigenik yang merangsang pembentukan antibodi, antibodi disekresi oleh sel plasma yang terbentuk melalui proliferasi dan differensial leukosit B. Jika ada antigen masuk ke dalam tubuh pada limfosit $\mathrm{B}$, ransangan antigen menyebabkan transformasi sel yang akhirnya menghasilkan sel-sel plasma. Sel plasma tersebut yang membentuk antibodi. Menurut Guyton (1983) menyatakan setiap antibodi bersifat spesifik untuk antigen tertentu. Hal ini disebabkan oleh struktur antibodi yang tersusun atas asam-asam amino pada bagian yang dapat berubah dari kedua rantai sederhana dan komplek.

\section{Serum Albumin}

Berdasarkan Tabel 6 pada hari ke-0 sampai hari ke-29 pemberian sampel menunjukkan penurunan jumlah nilai rataan serum albumin pada setiap perlakuan yang ditandai dengan nilai selisih yang negatif. Penurunan serum albumin yang terkecil pada perlakuan A3 (Pemberian Serbuk Ekstrak I dosis 40,5 mg/KgBB) dengan nilai selisih 0,11 (jumlah nilai rataan serum albumin $1,53 \mathrm{~g} / \mathrm{dl}$ ) dibandingkan perlakuan A1 (kontrol normal) dengan nilai selisih $-0,15$ (jumlah nilai rataan serum albumin 1,44g/dl), A2 (Pemberian Stimuno Forte dosis 1,35 mg/KgBB) dengan nilai selisih 0,23 (jumlah nilai rataan serum albumin 1,42g/dl), dan A4 (Pemberian Serbuk Ekstrak II dosis $81 \mathrm{mg} / \mathrm{KgBB}$ ) dengan nilai selisih 0,18 (jumlah nilai rataan serum albumin $1,53 \mathrm{~g} / \mathrm{dl})$.

Hasil penelitian menunjukan nilai serum albumin pada setiap perlakuan dibawah batas kisaran kadar albumin normal tikus jantan < 3,0-5,1g/dl (Sutedjo, 2007). Penurunan jumlah nilai rataan serum albumin pada setiap perlakuan menunjukan pengaruh biokimia tubuh yang sama, ketika pemberian sampel dimasukan kedalam tubuh hewan reaksinya sama, adapun penurunan jumlah serum albumin dapat disebabkan oleh kondisi tubuh, usia hewan coba, dan waktu paruh serum albumin yang mempunyai waktu paruh 8-20 hari didalam darah (Syamsiatun et al., 2015).

\section{Bobot Organ Limfoid}

Hasil perhitungan bobot organ limfoid relatif pada tikus Sprague Dawley dapat dilihat pada Tabel 7.

Tabel 7. Hasil Uji Bobot Organ Limfoid Relatif(\%)

\begin{tabular}{|c|c|c|c|c|c|}
\hline Parameter & $\mathrm{Al}$ & $\mathrm{A} 2$ & $\mathrm{~A} 3$ & $\mathrm{~A} 4$ & Normal \\
\hline $\begin{array}{l}\text { Bobot Limpa } \\
\text { Relatif }(\%) \\
\end{array}$ & 0,20 & 0,17 & 0,22 & 0,19 & $0,2 \cdot 0,3$ \\
\hline $\begin{array}{l}\text { Bobot Hati } \\
\text { Relatiff(\%) }\end{array}$ & 3,18 & 2,89 & 3,27 & 2,93 & $2,3 \cdot 3,3,1$ \\
\hline
\end{tabular}

\section{Bobot Limpa Relatif}

Limpa merupakan salah satu organ limfoid tempat pembentukan limfosit yang 
digunakan untuk masuk kedalam darah. Limpa bereaksi terhadap antigen yang terbawa darah dan merupakan organ pembentukan antibodi. Berdasarkan Tabel 7 pada parameter bobot limpa relatif nilai rataan terbesar yaitu pada perlakuan A3 (Pemberian Serbuk Ekstrak I dosis 40,5 $\mathrm{mg} / \mathrm{KgBB}$ ) sebesar $0,22 \%$ dibandingkan perlakuan A1 (kontrol normal) sebesar 0,20\%, A2 (Pemberian Stimuno Forte dosis $1,35 \mathrm{mg} / \mathrm{KgBB})$ sebesar $0,17 \%$, dan A4 (Pemberian Serbuk Ekstrak II dosis 81 mg/KgBB) sebesar 0,19\%. Hal ini menunjukan perlakuan A3 (Pemberian Serbuk Ekstrak I dosis 40,5 mg/KgBB) efektif dalam meningkatkan bobot limpa relatif adanya kandungan antioksidan pada perlakuan A3 (Pemberian Serbuk Ekstrak I dosis 40,5 mg/KgBB) berperan dalam respon imun tikus Sprague Dawley dengan meningkatnya bobot limpa relatif. Semakin tinggi bobot limpa maka semakin tinggi sel limfosit yang dihasilkan pembentukan antibodi (Aldi et al., 2016).

Parameter bobot limpa relatif berkaitan dengan sistem imun. Mekanisme kerja sistem imun didalam limpa, sel B menjadi aktif dan menghasilkan sejumlah besar antibodi yang terdiri dari sel-sel B, sel T, makrofag, sel darah merah, yang mampu menangkap benda asing antigen dari darah yang melewati limpa.

Hasil penelitian bobot organ limpa relatif menunjukan perlakuan A3 (Pemberian Serbuk Ekstrak I dosis 40,5 mg/KgBB) dan A1 (kontrol normal) masih dalam batas kisaran limpa tikus normal sebesar 0,2-0,3\% (Losco, 1992) sedangkan pada perlakuan A2 (Pemberian Stimuno Forte dosis 1,35 $\mathrm{mg} / \mathrm{KgBB}$ ) dan A4 (Pemberian Serbuk Ekstrak II dosis $81 \mathrm{mg} / \mathrm{KgBB}$ ) menunjukan hasil nilai rataan bobot limpa relatif dibawah nilai batas normal tikus.

Menurut Fry dan McGavin (2007) menyatakan salah satu faktor yang menyebabkan bobot limpa dapat berubah dipengaruhi oleh kondisi patologi pada tubuh yang berpengaruh langsung pada bobot limpa. Kondisi patologis yang sering menyebabkan peningkata bobot limpa relatif yaitu peningkatan sel sistem monosit, makrofag, dan peningkatan volume darah (kongesti) (Sabatino et al., 2013). Pada penelitian ini tikus yang digunakan tidak dilakukan infeksi dan masih dalam keadaan sehat (29 hari) sehingga nilai rataan bobot organ limpa relatif yang lebih kecil dapat disebabkan oleh variasi berat badan, umur, dan asupan pakan (Sihombing, 2011).

\section{Bobot Hati Relatif}

Hati merupakan salah satu organ limfoid. Pada imunologi, hati berperan dalam respon imun karena mengandung makrofag terfiksasi, mekanisme kerjanya yaitu sel-sel kuffer berperan dalam membersihkan sel mati dari sirkulasi darah dengan proses fagositosis yang kemudian disekresi kedalam empedu. Peningkatan bobot hati dapat mengindikasikan adanya peningkatan proliferasi sel-sel imun yang terdapat dalam organ tersebut (Faradilla dan Iwo, 2014).

Berdasarkan Tabel 7 menunjukan nilai rata-rata bobot hati relatif terbesar pada perlakuan A3 (Pemberian Serbuk Ekstrak I dosis 40,5 $\mathrm{mg} / \mathrm{KgBB})$ sebesar 3,27\% dibandingkan perlakuan A1 (kontrol normal) sebesar 3,18\%, A2 (Pemberian Stimuno Forte dosis 1,35 mg/KgBB) sebesar 2,89\%, dan perlakuan A4 (Pemberian Serbuk Ekstrak II dosis $81 \mathrm{mg} / \mathrm{KgBB}$ ) sebesar 2,93\%. Hal ini menunjukan pada perlakuan A3 (Pemberian Serbuk Ekstrak I dosis 40,5 mg/KgBB) efektif dalam meningkatkan bobot hati relatif. Nilai rataan tertinggi bobot hati dapat mengindikasikan adanya peningkatan proliferasi sel-sel imun yang terdapat dalam organ tersebut (Faradilla dan Iwo, 2014).

Hasil penelitian pada setiap perlakuan menunjukan nilai bobot hati relatif yang masih dalam kisaran normal bobot hati relatif tikus yaitu 2,3-3,1\% per bobot badan (Linder, 1992). Hal ini menunjukan pemberian sampel tidak memberikan efek toksik terhadap hewan coba yang masih dalam kondisi normal (sehat). 


\section{KESIMPULAN DAN SARAN}

\section{Kesimpulan}

Pemberian serbuk ekstrak rosela I dosis 40,5 mg/KgBB dapat mempertahankan fungsi sistem imun pada tikus Sprague Dawley dengan peningkatan nilai rata-rata jumlah neutrofil segmen sebesar $42,2 \%$, total serum protein sebesar $10,99 \mathrm{~g} / \mathrm{dl}$, bobot limpa relatif sebesar $0,22 \%$ dan bobot hati relatif sebesar 3,27\% yang masih dalam batas normal hewan coba dalam kondisi sehat sehingga dapat memberikan efek protektif terhadap serangan antigen.

\section{Saran}

Perlu adanya pemberian antigen agar aktivitas serbuk ekstrak rosela berpegaruh secara optimal terhadap sistem imun pada semua parameter uji sistem imun.

\section{DAFTAR PUSTAKA}

Aboderin, F. I. and Oyetayo,V. O. 2006. Hematological stidies of rats fed different doses of probiotic, Lactobacillus plantarum, Isolated from fermenting corn slurry. Pakistan J. Nutr. 5:102-105.

Aldi, Y., Dewi O. Novita, dan Uthia R. 2016. Uji imunomodulator dan Jumlah sel leukosit dari ekstrak daun kemangi (Ocimum basilicum L.) pada mencit putih jantan. Scientia vol 6 no.2, agustus 2016 [prosiding seminar nasional perkembangan teknisi sains farmasi dan klinik III 2013]. http://www.jurnalscientia.org/index.php /scientia/article/viewFile/58/76.

[diakses 26 juni 2018].

Atmadja, A.S., Kusuma, R., Dinata. F. 2016. Pemeriksaaan Laboratorium untuk membedakan infeksi bakteri dan infeksi virus. 43(6): 457-461.

Aprilia, R. P., Pramana, A. W. M. and Oktavianie, D. A. A. P. 2012. Specificity and sensitivity of thyroglobulin and serum protein profile of autoimmune thyroiditis model rat (Rattus norvegicus)
Induced by sodium iodide. [skripsi]. Program kedokteran hewan, Universitas Bratawijaya.

Azza, A., Abou-arab, Ferial M, Abu-Salem Esmat A. 2011. Polyfenolic content and antioxidant activity of Hibiscus sabdariffa calyx. Res. J. Med. Plant. (5):55 7-566.

Dwiyanti, G., K, Hati. N. 2014. Aktivitas Antioksidan Teh Rosela (Hibiscus Sabdariffa L.) Selama Penyimpanan Pada Suhu Ruang. 5(1) :1-6.

Etim, N. E. Enyinihi, U. Akpabiodan Edem. 2014. Effects of nutrition on haemotology of rabbits: A review. J. European Sci. 10(3): 431-423.

Faradilla, M., dan Iwo M. Immaculata. 2014. Efek imunomodulator Polisakarida rimpang temu kunci [Curcumazedoaria (Christm.) Roscoe] Rhizome. 12(2):273278.

Fatchiyat, Sriwidiyarti, L. A. Esti, dan R. Sri. 2011. Biologi Molekuler. Prinsip Dasar Analisis, Penerbit Erlangga. Jakarta.

Frandson, R. D. 1992. Anatomi dan Fisiologi. Edisi Empat. Gajah Mada University Press. Yogyakarta.

Fry, M. E, Mc Gavin, M., D. 2007. Bone Marrow, blood cells, and lymphatic system. Dalam: McGavin MD, Zachary JF. (Eds). Pathologic Basis of Veterinary Disease 4 th Edition. Missouri: Mosby Elsevier

Ganong, W. F. 1996. Buku Ajar Fisiologi KedoktSeran (Review of Medical Physiology). Penerbit EGC. Jakarta: 486510.

Guyton, Arthur C. 1983. Fisiologi Manusia dan Mekanismenya terhadap Penyakit. EGC, Jakarta.

Jain, N.C. 1993. Essential of Veterinary Hematology. Lea and Febiger, Philadelphia. Junqueirq, L. C. dan Carneiro, J. 2004. Histologi Dasar. Teks dan Atlas Edisi Kesepuluh. EGC. Penerbit Buku Kedokteran. Jakarta: 220-233.

Linder, M. C. 1992. Biokimia Nutrisi dan Metabolisme : dengan pemakaian secara klinis. UI Press, Jakarta.

Losco, P. 1992. Normal Development, Growth and Aging of the Spleen. Pathobiology of Aging Rat. Didalam: Cesta, M. F. 2006. 
Normal structure, function, and histology of the spleen. Toxicol Pathil 34:455-465.

Malvin, A. J. S. and O. R. William. 1993. Duke's Physiology of Domestic Animal. Ed ke-11. London:Cornel University Press.

Mardiah. 2014. Minuman Fungsional Berkarbonasi Yang Kaya Antioksidan

Berbasis Kelopak Bunga Rosela (Hibiscus Sabdariffa L.). 2(3): 1-4.

Mardiah, Zakaria, F. R. dan Prangdimurti, E. 2014. The Effect of Roselle (Hibiscus sabdariffa Linn.) On Blood Glucose Level And Total Antioxidant Level On Diabetic Rat Induced

Streptozotocin. 4(10):6- 16.

Mardiah, Zakaria, F. R., Prangdimurtia, E., dan Damanik R. 2015. Anti-inflammatory of purple roselle extract in diabetic rats induced by streptozotocin, the first international symposium on food and agro-biodiversity (ISFA2014). Procedia Food Science.3:182-189.

Nagrathan, P. K. M., Reens, K., Reddy, S., \& Wesley, J. 2013. Review on immunomodulation and immunomodulatory activity of some herbal plants. International Journal of Pharmaceutical Sciences Review and Research. 22(1):223- 230.

Nurarita, R., Praharani, D., Kusumawardani, B. 2012. Pengaruh Penyakit periodonal selama masa kehamilan terhadap jumlah total leukosit dan hitung jenis leukosit 9(3):125-130.

Primawati S. N. dan Khalid. 2015. Differential leukosit mencit (Mus musculus) pada evaluasi in vivo imunomodulator kurkumin kunyit putih (Curcumin zedoaria) [LPPM IKIP Mataram]. Pendidikan Biologi FPMIPA IKIP Mataram, Universitas Mataram, Mataram. 14(4):413-416.

Rahadian, R., Harun, N., dan Efendi, R. 2017. Pemanfaatan Ekstrak Kelopak Bunga Rosela (Hibiscus Sabdariffa L.) Dan Rumput Laut (Euchema cottoni) Terhadap Mutu Permen Jelly. 4(1) : 111.

Syamsiatun, N., Siswati, T., 2015. Pemberian ekstrak jus putih telur terhadap kadar albumin dan hb pada penderita hioalbuminemia. 12(2): 54-61.

Sastradipradja, D., S. H. S. Sikar, R. Wijayakusuma, T. Ungerer, A. Maad, H. Nasution, R. Suriawinata, dan R. Hamzah. 1989. Penuntun Praktikum Fisiologi Veteriner. Fakultas Peternakan. IPB, Bogor. Santoso, B. 2010. Differential couting berdasarkan zona baca atas dan bawah pada preparat darah apus. Prosiding seminar nasional UNIMUS [Internet]. http://jurnal.unimus.ac.id.ISBN:978.979.7 04.883.9. [diakses 26 Juni 2018].

Setiawan, 2013. Efektivitas aplikasi madu murni terhadap penyembuhan jaringan periodontal pada perawatan periodontitis penderita hipertensiked gi, 4 (4):228-235.

Sihombing, M., Tuminah, S. 2011. Perubahan Nialai Hematologi, Biokimia Darah, Bobot Organ dan Bobot Badan Tikus Putih pada Umur Berbeda. Jurnal Veteriner. 12 (1):5864.

Silalahi, J. 2006. Makanan Fungsional. Penerbit Kanisius Yokyakarta. Halaman 38-56.

Smith, J. B. dan Mangkoewidjojo, S. 1988. Pemeliharaan, Pembiakan, dan Penggunaan Hewan Percobaan di Daerah Tropis. Penerbit UI. Jakarta:34-40.

Sulaksana, J. dan Jayusman, D. I. (2004). Meniran: Budidaya dan pemanfaatan untuk obat. Jakarta: Penebar Swadaya

Sullivan, Ellen. 2006. Hematology Analyzer: From Workhorse to Thoroug:hbred. $37(5): 278$.

Sutedjo, S. K. M. 2007. Mengenal Penyakit Melalui Hasil Pemeriksaan Laboratorium. Amara Books, Yogyakarta.

Riswanto. 2013. Pemeriksaan Laboratorium Hematologi. Alfamedia, Yogyakarta

Kiswari, Rukman. 2014. Hematologi dan Transfusi. Erlangga. Jakarta.

Ulilalbab, A., Priyanto, A. D, Maulana, H. I., Puspitasari, F. R. 2010. Pemberian Tablet Effervescent Rosela Ungu Menurunkan Nilai MDA (Malondialdehid) Tikus Wistar Yang Dipapar Minyak Jelantah. Program studi Ilmu dan Teknologi Pangan, Universitas Brawijaya, Malang. The Indonesia Journal of Public Health. 9(1):81-86. 
Widyastuti, D. A. 2013. Profil Darah Tikus Putih Wistar pada Kondisi Subkronis Pemberian Natrium Nitrit. JSV 31(2):210213.

Wibowo, A. S. 2009. Efek imunostimulan ekstrak meniran (Phyllanthus niruri L.) secara in vivo pada tikus
(Immunostimulan Effect of Extract in vivo on Rat). Jurnal Bahan Alam Indonesia. Yati, K., Elfiyani, R., dan Permatasari, D. A. 2014. Formulasi Hard Molded Lozenges Ekstrak Kelopak Bunga Rosela (Hibiscus Sabdariffa L) Dengan Penambahan Kombinasi Corn Syrup Dan Manitol. 11(2):1- 15. 